\title{
THE MEASUREMENT AND METABOLISM OF THIAMIN AND OF A PYRIMIDINE STIMULATING YEAST FERMENTATION FOUND IN THE BLOOD CELLS AND URINE OF NORMAL INDIVIDUALS ${ }^{1}$
}

\author{
By ALICE T. GORHAM, JULES C. ABELS, ${ }^{2}$ ANNETTE L. ROBINS, AND \\ C. P. RHOADS
}

(From the Memorial Hospital, New York City)

(Received for publication October 9, 1941)

The methods usually employed at present to ascertain the existence of thiamin deficiency in man are based upon measurements of the amounts of the vitamin in the urine before and after its oral or parenteral administration $(1,2)$. Evidence is available, however, to indicate that only a fraction of the thiamin ingested in the normal diet is excreted unchanged $(3,4)$, and hence it is possible that the amount in the urine does not represent the true status of deficiency or sufficiency of the vitamin in the body as a whole. Measurement of the levels of circulating thiamin clearly is preferable, but insufficient information has been available hitherto concerning its distribution between the various constituents of the blood. Due to this fact, the presence of anemia, dehydration, or marked leukocytosis might provide misleading findings if only the levels in whole blood were employed.

No method has been at hand for the measurement of the minute amounts of thiamin contained in the cellular elements since neither the technique of Melnick (5), nor the thiochrome method of Hennessy (6) are sensitive enough to be used for this purpose. It has been possible, however, so to adapt the ultramicro-technique of Atkin, Schultz and Frey ( 7 ) that thiamin can be determined in either leukocytes or erythrocytes. The method was chosen, not only because of its sensitivity and accuracy, but also because it made possible the measurement of both thiamin and the pyrimidines capable of accelerating yeast fermentation (PAYF). ${ }^{3}$

From the similarity between the chemical struc-

1 The authors gratefully acknowledge the assistance given by Standard Brands, Inc., the Jane Coffin Childs Memorial Fund for Medical Research, and the Dazian Foundation.

2 Finney-Howell Fellow.

3 Pyrimidine accelerating yeast fermentation. tures of thiamin and the pyrimidine compounds known to accelerate yeast fermentation (8), it has been assumed that the latter substances are either precursors of thiamin or products of its breakdown. On the basis of this possibility the simultaneous measurement of both thiamin and the PAYF compound in blood cells and urine, after the administration of those substances, should provide new information concerning the metabolism of thiamin by the human organism. Experiments of this type have been published by Pollack et al. (4). They found that the parenteral administration of $100 \mathrm{mgm}$. of thiamin resulted in an increased urinary excretion of pyrimidine and concluded that in the normal individual pyrimidine is derived from thiamin.

This communication deals with (1) a method for the measurement of the thiamin and the PAYF content of blood cells and urine; (2) the amounts of thiamin and the PAYF compound in leukocytes and platelets, erythrocytes, and the urine of normal individuals; and (3) a study of the metabolism of thiamin by the normal human being.

\section{METHOD}

The techniques used for the quantitative determination of total thiamin and of the pyrimidine compound in the blood and urine are adaptations of the fermentation method of Schultz, Atkin and Frey $(7,8)$. They depend upon the principle that within certain limits both thiamin and PAYF cause a measurable increase in the rate of alcoholic fermentation by yeast of a suitable sugarsalt-buffer mixture.

In this communication the term "total thiamin" is employed to include all those substances capable of stimulating fermentation by yeast under the conditions of the experimental procedure.

\section{A. Determination of the total thiamin and $P A Y F$ in blood cells}

To obtain leukocytes and platelets, $25 \mathrm{ml}$. of oxalated blood are allowed to settle at room temperature for from 
2 to 3 hours and the cloudy supernatant plasma is removed. Stained smears made from this cloudy plasma show that it usually contains about 75 per cent leukocytes and 25 per cent platelets. The plasma then is centrifuged at 3000 r.p.m. and, when cleared, is poured off. The clump of white cells ${ }^{4}$ in the bottom of the tube is mixed with a small amount of isotonic sodium chloride and transferred by a capillary pipette to a graduated hematocrit tube. After the hematocrit value has been obtained at maximum packing, and from it the actual volume of white elements calculated, the cells and saline in the hematocrit tube are diluted with isotonic sodium chloride to the optimum concentration for the determination of their total thiamin content. This, in most instances, ranges from $0.005 \mathrm{ml}$. to $0.009 \mathrm{ml}$. of white cells per ml. of suspension. The concentration of leukocytes and platelets used for the determination of their PAYF content ranges from 0.04 to $0.08 \mathrm{ml}$. per ml. of suspension. Stained smears made from this suspension usually show only fragments of leukocytes apparently mixed with platelets. Such microscopic examination of the suspensions prepared is necessary in order to ascertain the nature of the cellular material, the thiamin content of which is to be measured.

It is possible frequently to separate the leukocytes from the platelets. The method of this separation depends upon the difference in the rates of sedimentation of platelets and leukocytes in plasma. The upper half of the cloudy supernatant plasma, which in from 2 to 3 hours separates away from the red cells, is centrifuged at only 300 r.p.m. for about 5 minutes. This procedure removes from the suspension proportionately more leukocytes than it does platelets. The upper half of the resulting cloudy supernatant plasma is again used for the isolation of the platelets, and this procedure is repeated 2 or 3 times. In that manner a suspension finally is obtained which microscopic examination reveals to be free of leukocytes. The concentration of platelets in that suspension is determined from its hematocrit value at maximum packing. It must be emphasized, however, that this technique is not uniformly successful and it is sometimes impossible to clear the leukocytes out of this mixture with the platelets.

In a similar manner a suspension of known concentration is made from sedimented erythrocytes. The concentrations which have been found to be most suitable for the determination of the total thiamin content range from 0.05 to $0.10 \mathrm{ml}$. of red cells per $\mathrm{ml}$. and for their PAYF content from 0.50 to 0.75 per $\mathrm{ml}$. of suspension.

The procedure of Atkin et al. (7) has been modified in the following manner for the determination of total thiamin in blood cells. A standard containing no thiamin is substituted for that which contains 10 micrograms of thiamin. The blood cell samples are prepared for assay by immersion of the Warburg cup, which contains $1 \mathrm{ml}$. of

4 Throughout this communication, by the term "white cells" is meant a mixture of platelets and leukocytes. the cell suspension, in a boiling water bath for 3 minutes. It has not been found necessary first to acidify the sample for assay. No loss of thiamin activity was observed in standards prepared without gelatin solution.

To measure only the PAYF compound already existing in the cell suspension, the free thiamin of the suspension is destroyed by the addition of sodium sulfite. Neutral sulfite solution splits thiamin quantitatively at room temperature to give 2-methyl-6-amino-pyrimidine-5-methylsulfonic acid. This sulfonic acid derivative is unable to stimulate the rate of yeast fermentation. The reaction is depicted in Figure 1. The PAYF, already existing

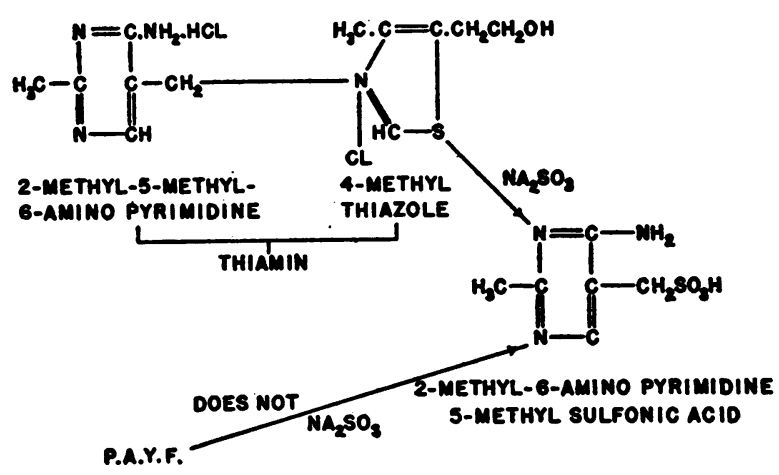

Fig. 1. The Action of Sulfite on Thiamin or PAYF

in the cell, is not converted to the sulfonic acid derivative and, therefore, remains free to stimulate the yeast fermentation.

One ml. of the red or white cell suspension is transferred to a $5 \mathrm{ml}$. cylinder graduated in $0.2 \mathrm{ml}$. divisions, and to it are added $0.1 \mathrm{ml}$. of $1.0 \mathrm{~N}$ sulfuric acid and $0.4 \mathrm{ml}$. of 10 per cent sodium sulfite. The graduate and its content are heated in a boiling water bath for 15 minutes to accelerate the cleavage.

The excess sulfite is removed with hydrogen peroxide, and the end point is determined by the use of an outside starch-iodide indicator. It is imperative that all the sulfite be removed, for traces of that substance inhibit the subsequent yeast fermentation.

The cell suspension in which the thiamin has been destroyed is brought to $\mathrm{pH} 6.8$ with $1.0 \mathrm{~N}$ sodium hydroxide and diluted to a volume to contain from 0.02 to $0.04 \mathrm{ml}$. of white cells per $\mathrm{ml}$. and from 0.10 to $0.15 \mathrm{ml}$. of red cells per $\mathrm{ml}$. One ml. samples of the sulfite-treated cell suspension are used in each Warburg cup.

In this communication the values of PAYF are expressed in terms of micrograms of thiamin which have an equivalent yeast-stimulating activity. It has been demonstrated (8) that the activity of 1 millimol of synthetic 2-methyl-5-methoxyethyl-6-amino-pyrimidine (158 mgm.) is equal to that of 1 millimol of the vitamin ( 337 mgm.).

The true thiamin finally is calculated as the difference between total thiamin and the PAYF. 


\section{B. Determination of total thiamin and $P A Y F$ in the urine}

No modifications have been made in the method of Schultz, Atkin and Frey (9) for the determination of total thiamin in the urine.

For the measurement of the PAYF in the urine, $20 \mathrm{ml}$. of the 24-hour urine collection are introduced into a 50 ml. volumetric flask. To this are added $1 \mathrm{ml}$. of $1.0 \mathrm{~N}$ sulfuric acid and $2 \mathrm{ml}$. of 10 per cent sodium sulfite. The sample is heated by immersion of the flask in a boiling water bath for 15 minutes. The excess sulfite is destroyed by 3 per cent hydrogen peroxide, and the acid present finally is neutralized with sodium hydroxide to pH 6.8. For the actual determination of thiamin, 5 to 10 ml. samples of the treated urine are used in each cup. The true thiamin value is calculated as the difference between the value for the total thiamin and that for the PAYF.

\section{RESULTS}

The material presented in this section includes (1) tests of the reliability of the techniques used; (2) measurements of thiamin and PAYF levels in the blood cells and urine of normal individuals; (3) evidence that these levels provide an index of thiamin sufficiency or deficiency in the body; and (4) evidence concerning the metabolism of thiamin by the normal individual.

\section{Experiments to test the reliability of the tech- niques used}

a. Reliability of method of the separation of erythrocytes from white cells (leukocytes and platelets). To test the completeness of the separation of red from white cells, the total thiamin

TABLE I

Evidence for the reliability of the technique employed to partition components of blood

\begin{tabular}{|c|c|c|c|}
\hline & Blood & $\begin{array}{c}\text { Total } \\
\text { thiamin }\end{array}$ & $\begin{array}{l}\text { Product in } \\
\text { micrograms }\end{array}$ \\
\hline M. B. & $\begin{array}{l}\mathrm{ml} . \text { per } \\
100 \mathrm{ml} \text {. }\end{array}$ & $\begin{array}{l}\text { micrograms } \\
\text { per } 100 \mathrm{ml} \text {. }\end{array}$ & \\
\hline $\begin{array}{l}\text { White blood cells. } \\
\text { Red blood cells... } \\
\text { Plasma ......... } \\
\text { Whole blood..... } \\
\text { H. M. }\end{array}$ & $\begin{array}{r}2.5 \\
42.0 \\
55.5\end{array}$ & $\begin{array}{r}57.6 \\
21.5 \\
.9 \\
11.5 \text { found }\end{array}$ & $\begin{array}{r}1.4 \\
9.0 \\
0.5 \\
10.9 \text { calculated }\end{array}$ \\
\hline $\begin{array}{l}\text { White blood cells. } \\
\text { Red blood cells... } \\
\text { Plasma ......... } \\
\text { Whole blood..... } \\
\text { E. C. }\end{array}$ & $\begin{array}{r}0.4 \\
39.3 \\
60.3\end{array}$ & $\begin{array}{r}256.0 \\
36.8 \\
3.6 \\
16.4 \text { found }\end{array}$ & $\begin{array}{r}1.0 \\
14.5 \\
2.2 \\
17.7 \text { calculated }\end{array}$ \\
\hline $\begin{array}{l}\text { White blood cells. } \\
\text { Red blood cells... } \\
\text { Plasma ......... } \\
\text { Whole blood.... }\end{array}$ & $\begin{array}{r}0.8 \\
12.5 \\
86.7\end{array}$ & $\begin{array}{r}250.0 \\
19.1 \\
1.6 \\
4.7 \text { found }\end{array}$ & $\begin{array}{l}2.0 \\
2.4 \\
1.4 \\
5.8 \text { calculated }\end{array}$ \\
\hline
\end{tabular}

concentrations were determined in samples of whole blood and in the red cells, white cells and plasma of those samples. Three such experiments were done and the sum of the amounts of total thiamin found is in good agreement with that found in an equivalent amount of whole blood (Table I).

b. Experiments to ascertain if thiamin is lost by the fragmentation of the white cells. In the course of preparation, the samples of isolated leukocytes and platelets are centrifuged in hematocrit tubes at high speeds. Microscopic examination of stained smears made from these suspensions frequently reveal only the presence of platelets and fragments of leukocytes. Although the saline from which the white cells have been separated in the hematocrit tubes also is used in the dilution of those cells to make the final suspension for thiamin measurement, it is necessary to determine whether or not thiamin is liberated into the plasma or saline by the leukocyte fragmentation.

TABLE II

Evidence to indicate that fragmentation of leukocytes does not result in a loss of thiamin

\begin{tabular}{l|c|c|c|c}
\hline \hline & \multicolumn{3}{|c}{ Millimicrograms of total thiamin in } \\
\cline { 2 - 5 } Individual & $\begin{array}{c}0.01 \mathrm{ml} . \\
\text { white cells } \\
\text { in } 1 \mathrm{ml} . \\
\text { of plasma }\end{array}$ & $\begin{array}{c}1 \mathrm{ml} . \\
\text { of plasma } \\
\text { alone }\end{array}$ & $\begin{array}{c}0.01 \mathrm{ml} . \\
\text { white cells } \\
\text { in } 1 \mathrm{ml} . \\
\text { saline }\end{array}$ & $\begin{array}{c}1 \mathrm{ml} . \\
\text { saline } \\
\text { alone }\end{array}$ \\
\hline H. R. & 26 & 0 & 28.6 & 0 \\
J. McK. & 17 & 0.2 & 18.6 & 0 \\
C. C. & & 16.0 & 0.5 \\
\hline
\end{tabular}

To ascertain the facts regarding this question, measurements were made of the total thiamin in plasma suspensions of white cells, in the cleared plasma after the white cells had been centrifuged out, in saline suspensions of the same white cells, and finally in samples of the saline suspensions cleared of their white cells. It was found (Table II) that, whereas the plasma suspensions of white cells contained significant amounts of total thiamin, the cleared plasma was practically thiamin free. Furthermore, the amount of total thiamin in the suspension of white cells in plasma equalled that in the same volume of white cells in saline. Centrifugation of the cells in saline, with their consequent fragmentation, liberated only from 0 to 3 per cent of the white cell total thiamin. 
It would appear, therefore, that leukocyte fragmentation does not entail a serious loss of total thiamin. It is probable that the thiamin is bound firmly to the solid insoluble matter of the white cells. This supposition is in accord with the findings of Banga, Ochoa, and Peters (10) who observed that no thiamin pyrophosphate could be separated from brain even when that tissue is ground up or heated to $100^{\circ} \mathrm{C}$.

c. The total thiamin content of platelets and leukocytes obtained from the same suspension of white cells. It has been indicated that the suspension of white cells obtained for their thiamin measurement consists of a mixture of platelets and leukocytes. Therefore, before it was permissible to compare the concentration of total thiamin in one mixture of white cell elements with that of another, it was necessary first to determine whether or not any significant difference existed between the concentrations of total thiamin in the leukocytes and in the platelets obtained from the same suspension of white cells.

By the refined technique previously described it was possible to separate from the white cell suspensions two fractions: one of pure platelets and the other of leukocytes with a small amount of platelets. Microscopic examination revealed that the latter fraction contained a concentration of leukocytes from 3 to 4 times that in the original white cell suspension, and for this experiment this fraction was considered to be one of leukocytes alone.

The data in Table III present two experiments in which total thiamin values were determined in equal volumes of platelets and of leukocytes obtained from the same sample of white cells. In the two experiments it was found that the thiamin contents of platelets were only 10 and 11 per cent less than those in the corresponding leukocytes.

It would appear, therefore, that since the total thiamin contents of leukocytes and platelets ob-

TABLE III

The thiamin content of platelets and leukocytes partitioned from the same samples of white cells

\begin{tabular}{|c|c|c|}
\hline Individual & \multicolumn{2}{|c|}{$\begin{array}{l}\text { Total thiamin in } \\
\text { Leukocytes }\end{array}$} \\
\hline & \multicolumn{2}{|c|}{ micrograms per $100 \mathrm{ml}}$. \\
\hline $\begin{array}{l}\text { H. R. . } \\
\text { S. K.. }\end{array}$ & $\begin{array}{ll}\ldots & 127 \\
\ldots & 190\end{array}$ & $\begin{array}{l}113 \\
170\end{array}$ \\
\hline
\end{tabular}

tained from the same samples of white cells are approximately equal, it is permissible to compare the concentrations of thiamin in one sample of white cells with that of another.

d. Recovery of thiamin and of PAYF added to whole blood, blood cell suspensions, and to urine. The data in Table IV present determinations

TABLE IV

Recovery of thiamin from whole blood and urine

\begin{tabular}{|c|c|c|c|}
\hline & $\begin{array}{l}\text { Millimicro- } \\
\text { grams of } \\
\text { thiamin added } \\
\text { to } 100 \mathrm{ml} \text {. } \\
\text { of sample }\end{array}$ & $\begin{array}{l}\text { Millimicro- } \\
\text { grams of } \\
\text { thiamin in } \\
100 \mathrm{ml} \\
\text { of sample }\end{array}$ & $\begin{array}{l}\text { Per cent } \\
\text { of } \\
\text { recovery }\end{array}$ \\
\hline Blood number 1 & $\begin{array}{l}0 \\
4\end{array}$ & $\begin{array}{r}8.9 \\
13.6\end{array}$ & $105^{\circ}$ \\
\hline Blood number 2 & $\begin{array}{r}0 \\
6 \\
10\end{array}$ & $\begin{array}{r}3.6 \\
9.0 \\
14.2\end{array}$ & $\begin{array}{r}94 \\
104\end{array}$ \\
\hline Blood number 3 & $\begin{array}{l}0 \\
2 \\
4 \\
6\end{array}$ & $\begin{array}{l}10.4 \\
12.0 \\
14.0 \\
16.2\end{array}$ & $\begin{array}{l}97 \\
97 \\
99\end{array}$ \\
\hline Blood number 4 & $\begin{array}{l}0 \\
4 \\
6 \\
8\end{array}$ & $\begin{array}{r}5.4 \\
9.5 \\
9.2 \\
12.7\end{array}$ & $\begin{array}{r}102 \\
80 \\
91\end{array}$ \\
\hline Blood number 5 & $\begin{array}{r}0 \\
10 \\
20\end{array}$ & $\begin{array}{r}4.0 \\
15.8 \\
26.5\end{array}$ & $\begin{array}{l}111.4 \\
109.4\end{array}$ \\
\hline Urine number 1 & $\begin{array}{r}0 \\
25\end{array}$ & $\begin{array}{l}36.25 \\
61.25\end{array}$ & 100 \\
\hline Urine number 2 & $\begin{array}{r}0 \\
\mathbf{5 0}\end{array}$ & $\begin{array}{r}3.75 \\
52.50\end{array}$ & 97.5 \\
\hline Urine number 3 & $\begin{array}{r}0 \\
50\end{array}$ & $\begin{array}{l}50.0 \\
88.75\end{array}$ & 88.75 \\
\hline
\end{tabular}

of total thiamin in 5 samples of blood and in 3 samples of urine before and after known amounts of thiamin had been added. The recovery of the vitamin added to the blood ranged from 80.0 per cent to 111.4 per cent, and of that added to the urine from 88.75 per cent to 100.0 per cent.

Table $\mathrm{V}$ presents the amounts recovered from samples of white cells, of erythrocytes and of urine to which varying amounts of 2-methyl-5methoxyethyl-6-amino-pyrimidine, a known accelerator of yeast fermentation (8), had been added. The recoveries of that substance added to the blood cell suspensions ranged from 93 per cent to 105 per cent, and of that added to urine from 92.8 per cent to 96.5 per cent. 
TABLE V

Recovery of 2-methyl-5-methoxyethyl-6-amino-pyrimidine from blood cells and urine

\begin{tabular}{|c|c|c|c|c|}
\hline Sample & $\begin{array}{l}\text { Micro- } \\
\text { grams* of } \\
\text { PAYF } \\
\text { found in } \\
100 \text { ml. of } \\
\text { sample }\end{array}$ & $\begin{array}{l}\text { Micro- } \\
\text { grams* of } \\
6 \text {-amino- } \\
\text { pyrimidine } \\
\text { added to } \\
100 \mathrm{ml} \text {. of } \\
\text { sample }\end{array}$ & $\begin{array}{l}\text { Micro- } \\
\text { grams* } \\
\text { of } \\
\text { PAYF } \\
\text { re- } \\
\text { covered }\end{array}$ & $\begin{array}{l}\text { Per } \\
\text { cent } \\
\text { of } \\
\text { re- } \\
\text { cov- } \\
\text { ery }\end{array}$ \\
\hline $\begin{array}{l}\text { White blood cells number } 1 \ldots \\
\text { White blood cells number } 2 . . \\
\text { White blood cells number } 3 .\end{array}$ & $\begin{array}{l}3.2 \\
3.4 \\
1.3\end{array}$ & $\begin{array}{l}20 \\
20 \\
20\end{array}$ & $\begin{array}{l}22.8 \\
24.4 \\
21.4\end{array}$ & $\begin{array}{r}93 \\
105 \\
101\end{array}$ \\
\hline $\begin{array}{l}\text { Red blood cells number } 1 \ldots \ldots \\
\text { Red blood cells number } 2 \ldots\end{array}$ & $\begin{array}{l}2.9 \\
3.3\end{array}$ & 20 & $\begin{array}{l}24.2 \\
23.4\end{array}$ & $\begin{array}{l}105 \\
101\end{array}$ \\
\hline $\begin{array}{l}\text { Urine number } 1 \ldots \ldots \ldots \ldots \ldots \\
\text { Urine number } 2 \ldots \ldots \ldots \ldots \ldots \\
\text { Urine number } 3 \ldots \ldots \ldots \ldots\end{array}$ & $\begin{array}{r}4.5 \\
44.5 \\
22.5\end{array}$ & $\begin{array}{l}50 \\
25 \\
50\end{array}$ & $\begin{array}{l}52.5 \\
64.5 \\
70.0\end{array}$ & $\begin{array}{l}94.5 \\
92.0 \\
96.5\end{array}$ \\
\hline
\end{tabular}

* Micrograms in thiamin equivalents.

These results indicate that the methods employed satisfactorily measure thiamin and the pyrimidine compound in blood and urine specimens.

\section{The concentration of total thiamin and $P A Y F$ in the blood cells and urine of normal individuals}

Determinations were made of the total thiamin in the white cells of 30 normal adults-18 females and 12 males-and in the erythrocytes of 24 of those same individuals -17 females and 7 males. The total thiamin of the white cells ranged from 48 to 183 micrograms per $100 \mathrm{ml}$. and averaged 99.8 micrograms per $100 \mathrm{ml}$. The total thiamin of the erythrocytes ranged from 3.7 to 38.0 micrograms per $100 \mathrm{ml}$. and averaged 10.3 micrograms per $100 \mathrm{ml}$. (Table VI, Figure 2).

The levels of PAYF were measured in the white cells of 10 of the 30 normal individuals studied, and in the red cells of 6 of the 24. The concentrations of the PAYF compound in the white cells ranged from 11 to 50 micrograms per $100 \mathrm{ml}$. and averaged 32.5 micrograms per $100 \mathrm{ml}$. The PAYF in these 10 instances accounted for from 16.8 per cent to 64 per cent of the total white cell thiamin measured. In the erythrocytes the PAYF concentrations ranged from 1.3 to $5.0 \mathrm{mi}-$ crograms per $100 \mathrm{ml}$. and averaged 3.0 micrograms per $100 \mathrm{ml}$. The PAYF accounted for from 14 per cent to 30 per cent of the total red cell thiamin.

The daily excretion of total thiamin and PAYF in the urine was followed in 8 normal individuals
TABLE VI

The concentrations of total thiamin, true thiamin and of $P A Y F$ in the blood cells of normal individuals

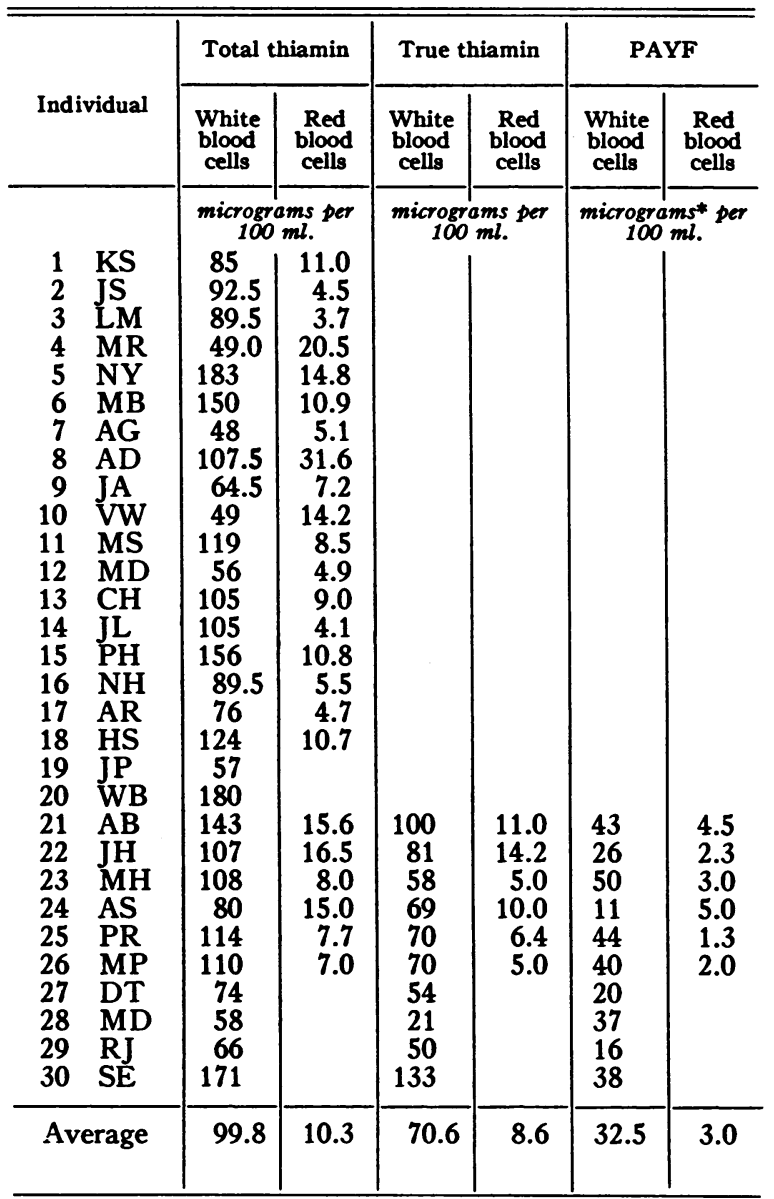

* Micrograms expressed in thiamin equivalents.

TABLE VII

Micrograms of thiamin and of PAYF excreted per day in the urine of normal individuals

\begin{tabular}{|c|c|c|c|c|c|c|c|c|}
\hline \multirow{2}{*}{$\underset{\text { ject }}{\text { Sub- }}$} & \multirow{2}{*}{ Weight } & \multirow{2}{*}{$\begin{array}{l}\text { Num- } \\
\text { ber } \\
\text { of } \\
\text { days }\end{array}$} & \multirow{2}{*}{$\begin{array}{c}\begin{array}{c}\text { Urinary } \\
\text { thiamin }\end{array} \\
\begin{array}{c}\text { Range } \\
\text { per day }\end{array}\end{array}$} & \multirow{2}{*}{$\begin{array}{l}\text { Av- } \\
\text { er- } \\
\text { age } \\
\text { per } \\
\text { day }\end{array}$} & \multirow{2}{*}{$\begin{array}{c}\text { High- } \\
\text { est } \\
\text { per } \\
\text { cent } \\
\text { daily } \\
\text { varia- } \\
\text { tion }\end{array}$} & \multirow{2}{*}{$\begin{array}{c}\begin{array}{c}\text { Urinary } \\
\text { PAYF* }\end{array} \\
\begin{array}{c}\text { Range } \\
\text { per day }\end{array}\end{array}$} & \multirow{2}{*}{$\begin{array}{l}\text { Av- } \\
\text { er- } \\
\text { age } \\
\text { per } \\
\text { day }\end{array}$} & \multirow{2}{*}{$\begin{array}{c}\text { High } \\
\text { est } \\
\text { per } \\
\text { cent } \\
\text { daily } \\
\text { varia- } \\
\text { tion }\end{array}$} \\
\hline & & & & & & & & \\
\hline $\begin{array}{l}\text { J.J. } \\
\text { J.H. } \\
\text { M.P. } \\
\text { N.N. } \\
\text { M.H. } \\
\text { A.B. } \\
\text { P.R. } \\
\text { A.S. }\end{array}$ & $\begin{array}{c}\text { kilos } \\
73 \\
82 \\
69 \\
53 \\
45 \\
61 \\
83 \\
42\end{array}$ & $\begin{array}{l}9 \\
6 \\
6 \\
4 \\
4 \\
2 \\
4 \\
3\end{array}$ & $\begin{array}{r}76-227 \\
179-421 \\
53-168 \\
140-348 \\
66-101 \\
25-63 \\
158-314 \\
158-296\end{array}$ & $\begin{array}{r}140 \\
350 \\
111 \\
270 \\
83 \\
44 \\
214 \\
229\end{array}$ & $\begin{array}{r}200 \\
135 \\
216 \\
143 \\
53 \\
152 \\
99 \\
87\end{array}$ & $\begin{array}{l}294-525 \\
351-910 \\
126-282 \\
215-300 \\
300-580 \\
169-220 \\
408-514 \\
222-332\end{array}$ & $\begin{array}{l}368 \\
556 \\
198 \\
263 \\
426 \\
194 \\
460 \\
250\end{array}$ & $\begin{array}{r}78 \\
159 \\
124 \\
40 \\
93 \\
35 \\
41 \\
50\end{array}$ \\
\hline
\end{tabular}

* Micrograms expressed in thiamin equivalents. 


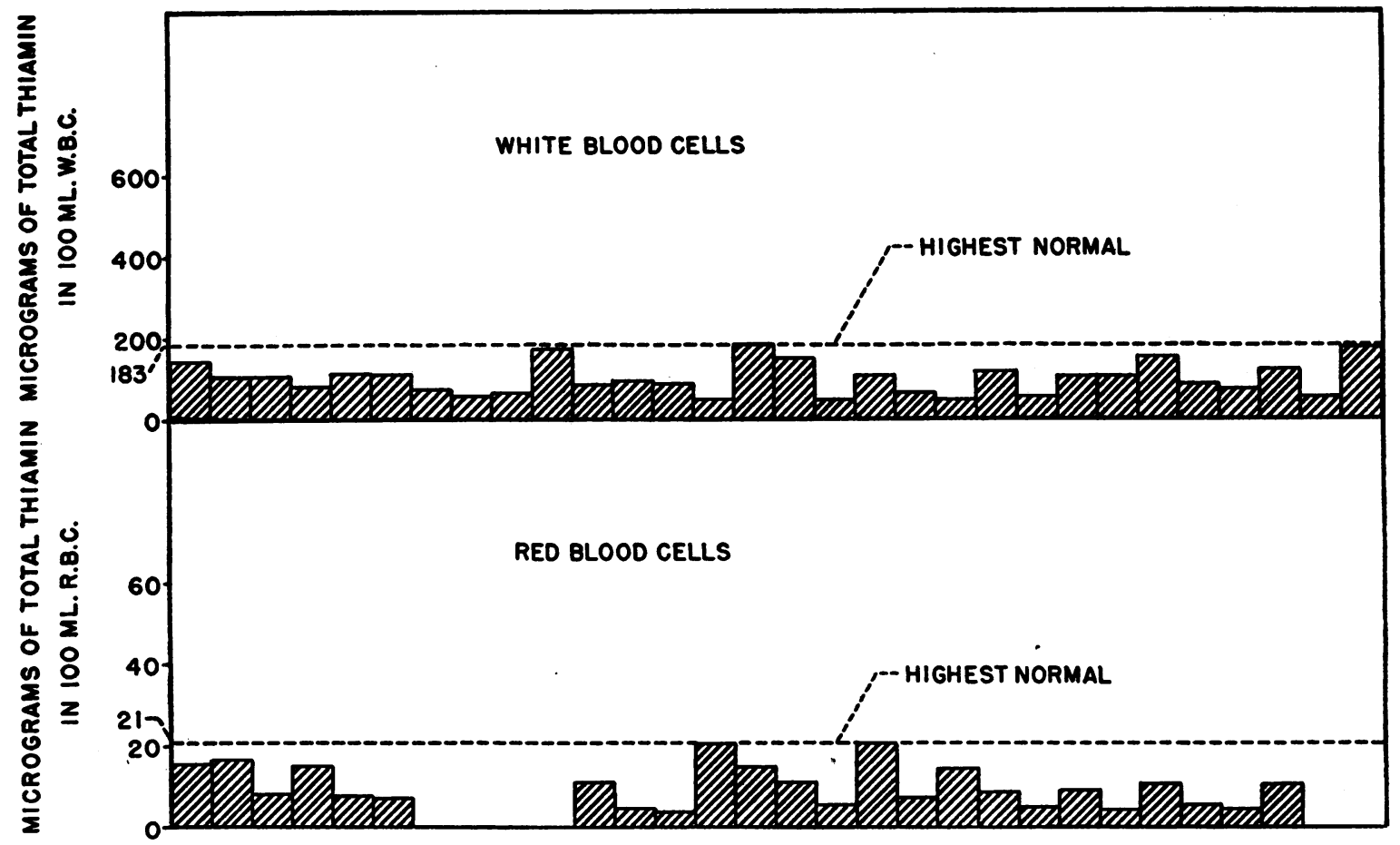

Fig. 2. The Levels of Total Thiamin in the Blood Cells of Normal Individuals

for periods of from 2 to 9 days. In all, 45 determinations were made. The average of the true thiamin excretion of each of 8 individuals ranged from 44 to 229 micrograms per day, and the average of the group was 168 micrograms per day. These values are in good agreement with those obtained by Schultz, Light and Frey (11). The average of the PAYF excretions of each of the 8 normals ranged from 194.5 to 556 micrograms per day, and the average of the group was 340 micrograms per day (Table VII). The highest percentage of daily variations of the thiamin excretion in the urine of these individuals was from 87 to 216 per cent, and that of the PAYF from 35 to 159 per cent.

\section{The correlation between the total thiamin levels in the blood cells and the ingestion of thiamin}

To ascertain if the blood cell total thiamin levels closely reflect the thiamin deficiency or saturation of the body, determinations were made in the cells of individuals $(a)$ who had clinical evidence of thiamin deficiency, and $(b)$ who had received supplements of the vitamin added to their diet. a. The blood cell total thiamin of patients with clinical evidence of thiamin deficiency. Table VIII presents analyses of total thiamin in the white cells and red cells of 4 individuals who had evidence of vitamin $B_{1}$ deficiency as ascertained

TABLE VIII

The concentrations of total thiamin in the blood cells of patients with clinical evidence of thiamin deficiency

\begin{tabular}{|c|c|c|c|c|}
\hline \multirow{2}{*}{ Patient } & \multirow{2}{*}{ Diagnosis } & \multirow[b]{2}{*}{ Symptoms } & \multicolumn{2}{|c|}{ Total thiamin } \\
\hline & & & $\begin{array}{l}\text { White } \\
\text { blood } \\
\text { cells }\end{array}$ & $\begin{array}{c}\text { Red } \\
\text { blood } \\
\text { cells }\end{array}$ \\
\hline \multirow{2}{*}{ JS } & \multirow[b]{2}{*}{$\begin{array}{l}\text { Ulcerative } \\
\text { colitis }\end{array}$} & \multirow[b]{2}{*}{$\begin{array}{l}\text { Anorexia } \\
\text { Diarrhea } \\
\text { Paresthesias }\end{array}$} & \multicolumn{2}{|c|}{$\begin{array}{l}\text { micrograms per } \\
100 \mathrm{ml} \text {. }\end{array}$} \\
\hline & & & 34.5 & 3.9 \\
\hline MS & $\begin{array}{l}\text { Pyloric } \\
\text { ulcer with } \\
\text { obstruction }\end{array}$ & $\begin{array}{l}\text { Polyneuritis } \\
\text { Absent knee jerks } \\
\text { Vomiting } \\
\text { Anorexia }\end{array}$ & 32.9 & 2.0 \\
\hline MR & $\begin{array}{l}\text { Cirrhosis } \\
\text { of liver, } \\
\text { alcoholism }\end{array}$ & $\begin{array}{l}\text { Peripheral edema } \\
\text { Absent knee jerks } \\
\text { Right ankle drop }\end{array}$ & 21.0 & 1.7 \\
\hline BL & $\begin{array}{l}\text { Chronic } \\
\text { inanition }\end{array}$ & $\begin{array}{l}\text { Marked anorexia } \\
\text { Weight loss } \\
\text { General inhibition } \\
\text { Paresthesias }\end{array}$ & 16.7 & 4.1 \\
\hline
\end{tabular}


from dietary history and physical examination. Urinary thiamin measurements were not being made when these patients were available.

The average white cell total thiamin of this group was 26.3 micrograms per $100 \mathrm{ml}$., or about 26 per cent of the normal value. The average red cell thiamin was 2.9 micrograms per $100 \mathrm{ml}$, or about 29 per cent cent of the normal.

b. The blood cell total thiamin of individuals who had ingested excess amounts of the vitamin. Table IX presents the values for total thiamin in the blood cells of 5 normal individuals who had been given daily doses of $10 \mathrm{mgm}$. of the crystalline vitamin orally for from 3 to 7 days.

All blood specimens of this group were taken from 20 to 24 hours after the last dose of thiamin was administered.

TABLE IX

The concentrations of total thiamin in the blood cells of individuals who received daily $10 \mathrm{mgm}$. supplements of thiamin

\begin{tabular}{|c|c|c|}
\hline Subject & $\begin{array}{l}\text { Tota } \\
\text { White blood } \\
\text { cells }\end{array}$ & $\begin{array}{l}\text { in } \\
\text { Red blood } \\
\text { cells }\end{array}$ \\
\hline & \multicolumn{2}{|c|}{ micrograms per $100 \mathrm{ml}}$. \\
\hline $\begin{array}{l}\text { RB. . } \\
\text { WS.. } \\
\text { JP... } \\
\text { NL.. } \\
\text { MM. }\end{array}$ & 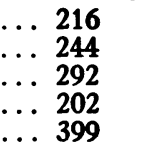 & $\begin{array}{l}\mathbf{5 3 . 5} \\
38.5 \\
18.7 \\
16.7 \\
16.3\end{array}$ \\
\hline
\end{tabular}

The average blood cell total thiamin levels of this group were 270.6 micrograms per $100 \mathrm{ml}$. of white cells and 28.8 micrograms per $100 \mathrm{ml}$. of erythrocytes. These average levels are about 3 times those found in the white and red cells of normal individuals who had not received supplements of the vitamin.

These high levels of total thiamin in the leukocytes and platelets of patients fed $10 \mathrm{mgm}$. of thiamin daily indicate that those cells normally are not saturated with the vitamin. If the administration of large amounts of thiamin to normal individuals only elevates their white cell levels of the vitamin and does not bring those levels all within the same narrow range, it would appear that normal white cells differ considerably in their capacity to absorb the vitamin. On the other hand, if it were demonstrated that the white cells of normal individuals can absorb only a limited and maximum amount of thiamin, despite the amounts of the vitamin supplements ingested, then low levels of thiamin in the leukocytes and platelets under normal conditions would indicate subclinical thiamin deficiency.

To ascertain the facts concerning this question, the total thiamin levels in the white cells of 8 normal individuals were determined before and, in 6 of the 8, after the daily administration of $100 \mathrm{mgm}$. of thiamin for 6 days (Table X).

TABLE $X$

Micrograms of total thiamin in $100 \mathrm{ml}$. of white cells of individuals who received daily $100 \mathrm{mgm}$. supplements of thiamin

\begin{tabular}{l|c|c|c}
\hline Subject & $\begin{array}{c}\text { Before ad- } \\
\text { ministration } \\
\text { of } \\
\text { thiamin }\end{array}$ & $\begin{array}{c}\text { 1 Day after oral } \\
\text { administration of } \\
600 \text { mgm. of } \\
\text { thiamin }\end{array}$ & $\begin{array}{c}8 \text { Days after } \\
\text { discontinuing oral } \\
\text { administration of } \\
\text { thiamin }\end{array}$ \\
\hline N. J. & 66 & 264 & 67 \\
J. P. & 57 & 263 & 100 \\
A. B. & 166 & 222 & 100 \\
D. T. & 74 & 207 & 86 \\
M. D. & 56 & 225 & 52 \\
S. E. & 171 & 210 & \\
J. H. & 94 & 208 & 113 \\
W. B. & 180 & 235 & 86 \\
\hline Average & 108 & 229 & \\
\hline
\end{tabular}

These 8 subjects had been taking apparently normal diets and no supplements of the vitamin for several weeks. The pre-therapeutic levels of total thiamin in their white cells ranged from 56 to 180 micrograms per $100 \mathrm{ml}$. and averaged 108 micrograms. After the daily ingestion of 100 milligrams of the vitamin for 6 days, the levels of total thiamin in those cells ranged from 207 to 265 micrograms per $100 \mathrm{ml}$. and averaged 229 micrograms, or twice the pre-therapeutic level. These increased levels are in the same range as those found in the leukocytes and platelets of 4 of the 5 patients who received only 10 milligrams of thiamin each day for 1 week. Finally, 8 days after the daily feeding of the 100 milligram doses of the vitamin had been discontinued, the white cell levels of total thiamin of 6 of the 8 subjects had fallen again to from 52 to 113 micrograms per $100 \mathrm{ml}$. This post-therapeutic level was not determined in the white cells of the other 2 subjects.

The fact is to be emphasized that, whereas the variation of total thiamin in the white cells of individuals before their ingestion of excess amounts of the vitamin is as high as 220 per cent, the variation after the thiamin administration is only 28 per cent. Hence, it might be concluded that white cells do not differ widely in their 
capacity to absorb thiamin, but can absorb only a limited amount of the substance. This fact would suggest, therefore, that individuals who are taking an apparently normal diet but who have low leukocyte and platelet levels of total thiamin possibly are in a clinical or subclinical deficiency state as regards vitamin $B_{1}$.

The intravenous administration of $1 \mathrm{mgm}$. of crystalline thiamin to 2 normal individuals also raised the levels of total thiamin in the leukocytes and platelets. In the case of N. Y., the white cell total thiamin level promptly rose from 140 micrograms to 850 micrograms per $100 \mathrm{ml}$. within 1 hour, but gradually returned to its original value by the next day. The white cell total thiamin level of M. R. also rose from 49 to 160 micrograms per $100 \mathrm{ml}$. of cells within 1 hour after the thiamin injection and returned to its original level by the next day. No significant changes were observed in the levels of total thiamin of the erythrocytes of these 2 individuals after the 1 mgm. dose.

Therefore, from the evidence presented, it may be concluded that the level of total thiamin in the white cells, and perhaps in the erythrocytes, is an index of the degree of thiamin saturation of the organism.

\section{The metabolism of thiamin by the normal individuals}

The thiamin molecule is composed of two nuclei : the pyrimidine and the thiazol (Figure 1). The fact has been established that yeast and other forms of plant life can synthesize thiamin from the derivatives of pyrimidine which hydrolyze in solution to form 2-methyl-5-hydroxymethyl-6amino-pyrimidine (12).

The vitamin also is broken down by these microorganisms with the destruction of the thiazol ring and liberation of the free pyrimidine (13). No such mechanism has been proved to occur in the animal. Robbins et al. (14) found that, while the polyneuritis of pigeons could be cured by feeding a mixture of pyrimidine and thiazol, the amounts needed were several thousand times that of an equivalent and curative amount of thiamin. They concluded, therefore, that pigeons had only a slight capacity for the synthesis of the vitamin from its two nuclei. In the human it is unknown whether the pyrimidine compound is a precursor or a break- down product of thiamin, or, indeed, if it bears any metabolic relationship to the vitamin at all.

In their study of the specificity of thiamin in the acceleration of yeast fermentation, Schultz, Atkin and Frey (8) tested numerous pyrimidine derivatives. They were able to show that of all the pyrimidine compounds tested for thiaminlike, yeast-stimulating activity, only 2-methyl-5hydroxymethyl-6-amino-pyrimidine, or compounds which in solution conceivably could hydrolyze to form that substance, possessed such activity. As previously indicated, compounds which could hydrolyze to form this hydroxy derivative do not form a sulfonate with the sulfite used to cleave the thiamin, but remain free to accelerate the fermentation. On the other hand, the pyrimidine nucleus which is split from the thiazol by sulfite is converted immediately into a sulfonate which lacks the yeast-stimulating activity.

Since a sensitive and accurate method was at hand for the measurements of thiamin and the active $\mathrm{PAYF}$, it was possible to investigate the relationship in man between these two compounds. The existence in the blood and urine of two substances with similar chemical structure suggested that the PAYF is either a precursor, or, more likely, in view of Robbin's experiments (14), a metabolite of thiamin. Two other possibilities, however, existed: that either thiamin or the pyrimidine might be converted to the other, or that there is no metabolic relationship between the two substances.

It was thought that the facts concerning this question could be ascertained by the administration of test doses of thiamin and of a pyrimidine compound known to be an active accelerator of yeast fermentation, and then by measurement of the changes effected in the concentrations of these substances in the white cells and urine. Two pyrimidines were available for this purpose: one, the synthetic 2-methyl-5-methoxyethyl-6-aminopyrimidine ( 8 ), and the other, the pyrimidine formed by the alkaline cleavage of thiamin. ${ }^{5}$

5 The latter substance was prepared by Dr. L. Atkin of the Fleischmann Laboratories by heating at $115^{\circ}$ for 4 hours a solution of thiamin at $\mathrm{pH}$ 6.4. After the thiamin molecule was cleaved, the solution was acidified to pH 5. This solution finally contained 576 micrograms per $\mathrm{ml}$. of an active pyrimidine (expressed in thiamin equivalents) and 67 micrograms per ml. of thiamin. 
If thiamin is converted during the course of its activity into an active pyrimidine compound, then the administration of the vitamin should increase the white cell content both of thiamin and of PAYF. The administration of the pyrimidine compound, on the other hand, should increase only the white cell content of PAYF. Conversely, if the PAYF is a precursor of thiamin, then the administration of the pyrimidine should increase both the PAYF and thiamin of the white cells, but the administration of thiamin should be followed only by an increased white cell thiamin.

The study of the metabolism of thiamin by the blood cells of human beings was made on 5 normal adults, 3 females and 2 males. All were on satisfactory diets, without supplements of vitamin $B_{1}$. The concentrations of true thiamin and of the PAYF in the white cells, erythrocytes and urine were determined for each subject 12 hours after the last ingestion of food. Then each was given intravenously $5 \mathrm{mgm}$. of thiamin and several days later, under the same conditions, $5 \mathrm{mgm}$. of an active pyrimidine. Determinations of the levels of true thiamin and of the PAYF in the blood cells were made, 1,3 , and 24 hours after each injection (Table XI, Figures 3,4 ). In addition, the concentrations of true thiamin and PAYF were ascertained in the urine of 9 normal individuals collected through the 1 st hour, from the 1 st to the 3rd, and from the 3rd to the 24th hour after the administration of the test substances. All the blood and the first 2 urine specimens were obtained when the subject was in the fasting state.

The levels of true thiamin and the PAYF in the white cells, rather than those in the erythrocytes, were used as an index of the absorption of those substances by the body, because earlier experiments (cited in Section IIIb) indicated that the intravenous administration of $1 \mathrm{mgm}$. doses of the vitamin to normal individuals produced a marked rise in the white cell total thiamin level but no significant changes in the red cell level.

a. Results after the intravenous administration of $5 \mathrm{mgm}$. of thiamin. The intravenous administration of $5 \mathrm{mgm}$. of thiamin to the normal subjects was followed within 3 hours by increases in the levels of true thiamin in the white cells (Figure 3). These levels ranged from 80 per cent to 132 per cent above their original values. The average increase was 100 per cent. In all instances, the administration of thiamin also produced within the first 3 hours significant increases in the white cell levels of PAYF. The posttreatment levels ranged from 41 per cent to 180

TABLE XI

The concentrations of true thiamin and of $P A Y F^{*}$ in the white cells and erythrocytes of normal individuals given thiamin and 2-methyl-5-methoxyethyl-6-amino-pyrimidine

\begin{tabular}{|c|c|c|c|c|c|c|}
\hline \multirow{2}{*}{ Subject } & \multirow{2}{*}{ Injection } & \multirow{2}{*}{$\begin{array}{l}\text { Hours } \\
\text { after } \\
\text { injec- } \\
\text { tion }\end{array}$} & \multicolumn{2}{|c|}{$\begin{array}{l}\text { White blood } \\
\text { cells }\end{array}$} & \multicolumn{2}{|c|}{$\begin{array}{l}\text { Red blood } \\
\text { cells }\end{array}$} \\
\hline & & & $\begin{array}{l}\text { True } \\
\text { thia- } \\
\text { min }\end{array}$ & PAYF & $\begin{array}{l}\text { True } \\
\text { thia- } \\
\text { min }\end{array}$ & PAYF \\
\hline \multirow{3}{*}{ J. H. } & & & $\begin{array}{l}\text { microgr } \\
100\end{array}$ & $\begin{array}{l}\text { ams per } \\
\text { ml. }\end{array}$ & microg & $\begin{array}{l}\text { ams per } \\
\text { ml. }\end{array}$ \\
\hline & $5 \mathrm{mgm} . \mathrm{B}_{1}$ & $\begin{array}{r}0 \\
1 \\
3 \\
24\end{array}$ & $\begin{array}{c}81 \\
155 \\
78 \\
90\end{array}$ & \begin{tabular}{|}
26 \\
35 \\
71 \\
26
\end{tabular} & $\begin{array}{r}14.2 \\
11.5 \\
8.6 \\
13.5\end{array}$ & $\begin{array}{l}2.3 \\
2.3 \\
9.7 \\
2.6\end{array}$ \\
\hline & $5 \mathrm{mgm} .6 \mathrm{AP}$ & $\begin{array}{r}0 \\
1 \\
3 \\
24\end{array}$ & $\begin{array}{l}68 \\
66 \\
84 \\
45\end{array}$ & $\begin{array}{r}97 \\
130 \\
47 \\
32\end{array}$ & $\begin{array}{c}11.2 \\
0 \\
13.0 \\
13.1\end{array}$ & $\begin{array}{r}2.4 \\
18.0 \\
2.4 \\
4.3\end{array}$ \\
\hline \multirow[t]{2}{*}{ P. R. } & $5 \mathrm{mgm} . \mathrm{B}_{1}$ & $\begin{array}{r}0 \\
1 \\
3 \\
24\end{array}$ & $\begin{array}{r}50 \\
105 \\
95 \\
56\end{array}$ & $\begin{array}{l}16 \\
40 \\
25 \\
15\end{array}$ & $\begin{array}{r}6.3 \\
5.0 \\
12.0 \\
7.6\end{array}$ & $\begin{array}{l}1.1 \\
2.1 \\
5.6 \\
2.2\end{array}$ \\
\hline & $5 \mathrm{mgm} .6 \mathrm{AP}$ & $\begin{array}{r}0 \\
1 \\
3 \\
24\end{array}$ & $\begin{array}{r}70 \\
30 \\
63 \\
330\end{array}$ & $\begin{array}{r}44 \\
50 \\
194 \\
70\end{array}$ & $\begin{array}{c}6.4 \\
8.1 \\
15.0 \\
0\end{array}$ & $\begin{array}{c}1.3 \\
5.7 \\
15 \\
10\end{array}$ \\
\hline \multirow[t]{2}{*}{ A. B. } & $5 \mathrm{mgm} . \mathrm{B}_{1}$ & $\begin{array}{r}0 \\
1 \\
3 \\
24\end{array}$ & $\begin{array}{c}100 \\
232 \\
32.5 \\
66.5\end{array}$ & $\begin{array}{l}43 \\
42 \\
98.5 \\
33.5\end{array}$ & $\begin{array}{r}11.1 \\
7.7 \\
11.8 \\
8.2\end{array}$ & $\begin{array}{l}4.5 \\
4.4 \\
4.5 \\
4.0\end{array}$ \\
\hline & $5 \mathrm{mgm} .6 \mathrm{AP}$ & $\begin{array}{r}0 \\
1 \\
3 \\
24\end{array}$ & $\begin{array}{c}100 \\
66 \\
96.5 \\
131\end{array}$ & $\begin{array}{l}43 \\
80 \\
71.5 \\
40\end{array}$ & $\begin{array}{r}7.2 \\
9.2 \\
13.6 \\
1.2\end{array}$ & $\begin{array}{r}3.0 \\
11.4 \\
3.4 \\
3.3\end{array}$ \\
\hline \multirow[t]{2}{*}{ M. H. } & $5 \mathrm{mgm} . \mathrm{B}_{1}$ & $\begin{array}{r}0 \\
1 \\
3 \\
24\end{array}$ & $\begin{array}{r}50 \\
89 \\
77 \\
369\end{array}$ & $\begin{array}{l}29 \\
41 \\
40 \\
13\end{array}$ & $\begin{array}{l}3.0 \\
8.7 \\
8.4 \\
5.3\end{array}$ & $\begin{array}{l}7.0 \\
5.5 \\
4.2 \\
1.1\end{array}$ \\
\hline & $5 \mathrm{mgm} .6 \mathrm{AP}$ & $\begin{array}{r}0 \\
1 \\
3 \\
24\end{array}$ & $\begin{array}{l}58 \\
33 \\
83 \\
90\end{array}$ & \begin{tabular}{|r}
50 \\
235 \\
59 \\
10
\end{tabular} & $\begin{array}{l}3.2 \\
0 \\
7.1 \\
9.0\end{array}$ & $\begin{array}{r}5.0 \\
16.1 \\
7.2 \\
5.0\end{array}$ \\
\hline \multirow[t]{2}{*}{ A. $S$. } & $5 \mathrm{mgm} . \mathrm{B}_{1}$ & $\begin{array}{r}0 \\
1 \\
3 \\
24\end{array}$ & $\begin{array}{l}165 \\
236 \\
236 \\
148\end{array}$ & $\begin{array}{r}31 \\
61 \\
40 \\
8\end{array}$ & $\begin{array}{r}12.5 \\
11.7 \\
3.2 \\
9.7\end{array}$ & $\begin{array}{l}2.1 \\
3.8 \\
4.5 \\
3.1\end{array}$ \\
\hline & $5 \mathrm{mgm} .6 \mathrm{AP}$ & $\begin{array}{r}0 \\
1 \\
3 \\
24\end{array}$ & $\begin{array}{r}69 \\
53 \\
52 \\
106\end{array}$ & $\begin{array}{l}11 \\
67 \\
45 \\
34\end{array}$ & $\begin{array}{r}10.0 \\
7.4 \\
8.5 \\
3.7\end{array}$ & $\begin{array}{r}5.0 \\
11.1 \\
1.5 \\
10.0\end{array}$ \\
\hline
\end{tabular}

* PAYF expressed in micrograms of thiamin equivalents. 


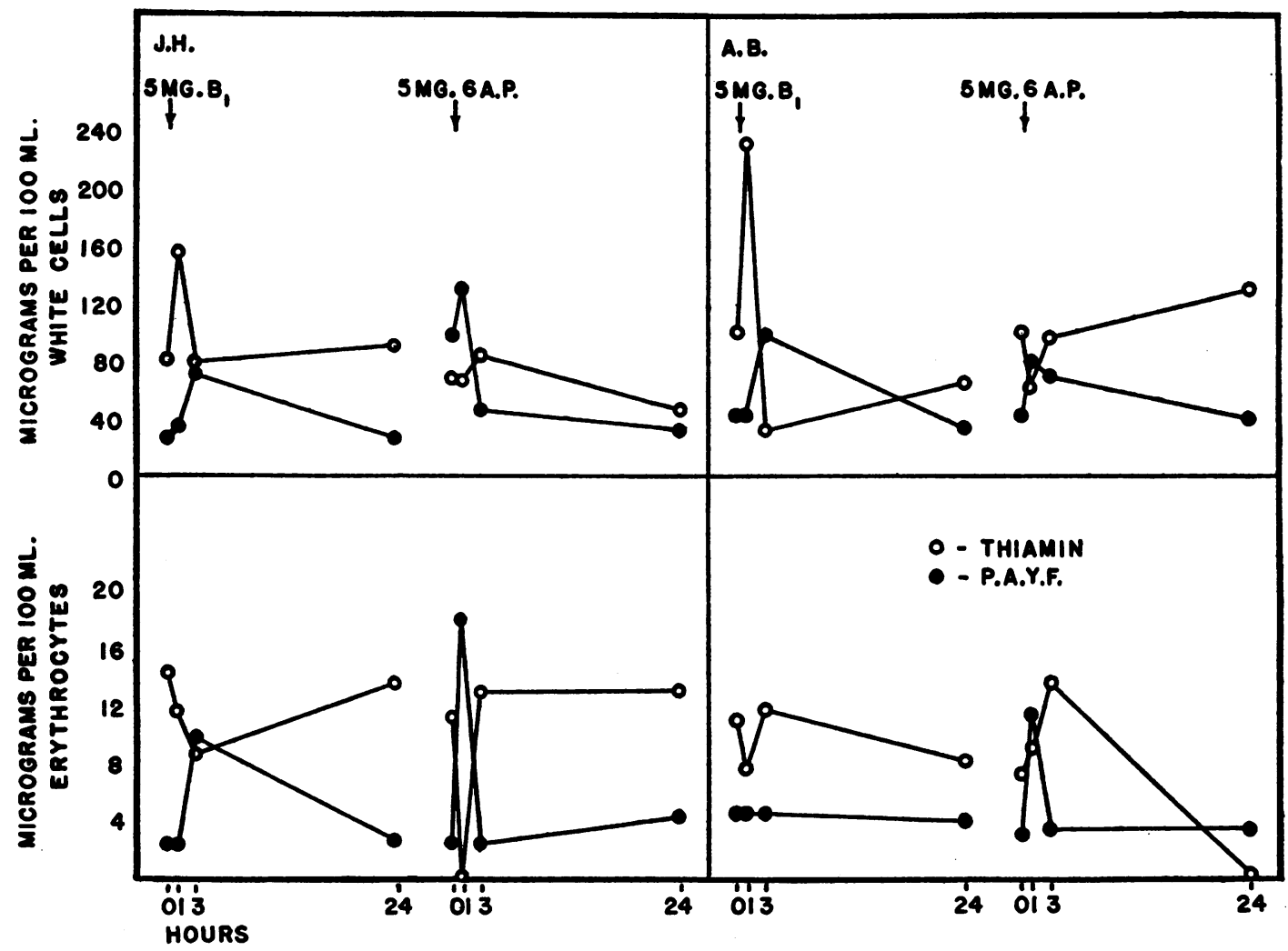

Fig. 3. The Levels of Thiamin and of PAYF in White Cells and Erythrocytes of Normal Individuals after the Intravenous Administration of Mgm. of Thiamin and 5 Mgm. of 2-Methyl5-MethoXyethYL-6-Amino-Pyrimidine

per cent of the original value, and averaged 143 per cent.

The concentrations of both true thiamin and the PAYF in the white cells tended to return to their base levels within 24 hours. Only in the subject M. H. did the thiamin level at 24 hours continue to rise.

The levels of true thiamin and the PAYF in the erythrocytes changed in a much less consistent manner after the administration of the vitamin. The erythrocyte true thiamin level rose in only 2 of the 5 subjects, and the PAYF in 3.

The urinary excretions of true thiamin and of the PAYF during the next 24 hours were increased significantly in all of 8 subjects who received injections of the vitamin (Tables XII, XIII, Figure 4). The true thiamin outputs in the 24 hours after the injection ranged from 51 per cent to 1610 per cent above the outputs of the previous day and from 121 per cent to 835 per cent above the average of the true thiamin ex- creted during all of the control days. The excretions of PAYF ranged from 52 per cent to 276 per cent above those of the previous day, and from 89

TABLE XII

Micrograms of thiamin excreted per day in the urine $o_{,}$ individuals before and after the intravenous injection of thiamin

\begin{tabular}{|c|c|c|c|c|c|c|c|}
\hline \multirow{3}{*}{ Subject } & \multicolumn{4}{|c|}{ Control period } & \multicolumn{3}{|c|}{ After injection } \\
\hline & \multirow{2}{*}{$\begin{array}{c}\text { Num- } \\
\text { ber } \\
\text { of } \\
\text { days }\end{array}$} & \multirow{2}{*}{$\begin{array}{l}\text { Urinary } \\
\text { thiamin } \\
\text { range per } \\
\text { day }\end{array}$} & \multirow{2}{*}{$\begin{array}{l}\text { Aver- } \\
\text { age } \\
\text { per } \\
\text { day }\end{array}$} & \multirow{2}{*}{$\begin{array}{l}\text { Highest } \\
\text { per cent } \\
\text { daily } \\
\text { variation }\end{array}$} & \multirow{2}{*}{$\begin{array}{l}\text { 24- } \\
\text { hour } \\
\text { out- } \\
\text { put }\end{array}$} & \multicolumn{2}{|c|}{$\begin{array}{c}\text { Per cent } \\
\text { increase over }\end{array}$} \\
\hline & & & & & & $\begin{array}{l}\text { Pre- } \\
\text { vious } \\
\text { day }\end{array}$ & $\begin{array}{l}\text { Aver- } \\
\text { age } \\
\text { con- } \\
\text { trol } \\
\text { day }\end{array}$ \\
\hline $\begin{array}{l}\text { J. J. } \\
\text { J. H. } \\
\text { M. P. } \\
\text { N. N. } \\
\text { M. H. } \\
\text { A. B. } \\
\text { P. R. } \\
\text { A. S. }\end{array}$ & $\begin{array}{l}9 \\
6 \\
6 \\
5 \\
4 \\
2 \\
4 \\
3\end{array}$ & $\begin{array}{r}76-227 \\
179-421 \\
53-168 \\
140-348 \\
66-101 \\
25-63 \\
158-314 \\
158-296\end{array}$ & $\begin{array}{r}140 \\
235 \\
111 \\
270 \\
83 \\
44 \\
214 \\
229\end{array}$ & $\begin{array}{r}200 \\
135 \\
216 \\
143 \\
53 \\
152 \\
99 \\
87\end{array}$ & $\begin{array}{r}760 \\
1530 \\
714 \\
1465 \\
726 \\
411 \\
474 \\
859\end{array}$ & $\begin{array}{r}538 \\
300 \\
1249 \\
991 \\
1000 \\
1610 \\
51 \\
190\end{array}$ & $\begin{array}{l}442 \\
551 \\
543 \\
442 \\
775 \\
835 \\
121 \\
275\end{array}$ \\
\hline
\end{tabular}


TABLE XIII

Micrograms of PAYF* excreted per day in the urine of individuals before and after the intravenous injection of thiamin

\begin{tabular}{|c|c|c|c|c|c|c|c|}
\hline \multirow{3}{*}{ Subject } & \multicolumn{4}{|c|}{ Control period } & \multicolumn{3}{|c|}{ After injection } \\
\hline & \multirow{2}{*}{$\begin{array}{c}\text { Num- } \\
\text { ber } \\
\text { of } \\
\text { days }\end{array}$} & \multirow{2}{*}{$\begin{array}{l}\text { Urinary } \\
\text { PAYF } \\
\text { range per } \\
\text { day }\end{array}$} & \multirow{2}{*}{$\begin{array}{l}\text { Aver- } \\
\text { age } \\
\text { per } \\
\text { day }\end{array}$} & \multirow{2}{*}{$\begin{array}{l}\text { Highest } \\
\text { per cent } \\
\text { daily } \\
\text { variation }\end{array}$} & \multirow{2}{*}{$\begin{array}{l}\text { 24- } \\
\text { hour } \\
\text { out- } \\
\text { put }\end{array}$} & \multicolumn{2}{|c|}{$\begin{array}{l}\text { Per cent } \\
\text { increase over }\end{array}$} \\
\hline & & & & & & $\begin{array}{l}\text { Pre- } \\
\text { vious } \\
\text { day }\end{array}$ & $\begin{array}{l}\text { Aver- } \\
\text { age } \\
\text { con- } \\
\text { trol } \\
\text { day }\end{array}$ \\
\hline $\begin{array}{l}\text { J. J. } \\
\text { J. H. } \\
\text { M. P. } \\
\text { N. N. } \\
\text { M. H. } \\
\text { A. B. } \\
\text { P. R. } \\
\text { A. S. }\end{array}$ & $\begin{array}{l}9 \\
6 \\
6 \\
5 \\
4 \\
2 \\
4 \\
3\end{array}$ & $\begin{array}{l}294-525 \\
351-910 \\
126-282 \\
215-300 \\
300-580 \\
169-220 \\
408-574 \\
222-332\end{array}$ & $\begin{array}{l}368 \\
556 \\
198 \\
263 \\
426 \\
194 \\
460 \\
250\end{array}$ & $\begin{array}{r}78 \\
159 \\
124 \\
40 \\
93 \\
35 \\
41 \\
50\end{array}$ & $\begin{array}{r}1280 \\
2930 \\
561 \\
805 \\
862 \\
479 \\
870 \\
530\end{array}$ & $\begin{array}{r}276 \\
222 \\
198 \\
258 \\
187 \\
116 \\
52 \\
60\end{array}$ & $\begin{array}{r}248 \\
428 \\
183 \\
207 \\
102 \\
147 \\
89 \\
112\end{array}$ \\
\hline
\end{tabular}

* Expressed in micrograms of thiamin equivalents.

per cent to 428 per cent above the average PAYF excretions of all the control days. In each subject the injection of thiamin resulted in increased outputs of both thiamin and of pyrimidine. These were too great to be explained by the normal daily variation.

From the evidence presented, therefore, it would appear that the intravenous injection of thiamin into normal individuals is followed consistently by significantly increased white cell and urinary concentrations of thiamin and of PAYF.

b. Results of the intravenous administration of the active pyrimidine compounds. The administration of 5 mgm. ${ }^{6}$ of 2-methyl-5-methoxyethyl-6amino-pyrimidine to 5 normal individuals increased within the first 3 hours their white cell concentrations of PAYF from 34 per cent to 660 per cent above the base levels (Figure 3 ). The average increase of the white cell level of PAYF was 333 per cent. The level of true thiamin in the white cells was elevated in only 1 subject (M. H.) 3 hours after the injection, but in 3 subjects 24 hours after the injection. In the erythrocytes the injection of the synthetic 6-amino-pyrimidine was followed by increased concentrations of the PAYF which ranged from 220 per cent to 1000 per cent; the average increase was 492 per cent. In 3 individuals the true thiamin levels of the red cells also were increased significantly, from 88

6 This amount of 2-methyl-5-methoxyethyl-6-aminopyrimidine is equivalent to $10.6 \mathrm{mgm}$. of thiamin. per cent to 130 per cent and the levels of both true thiamin and of PAYF did not return in all instances to their base levels 24 hours after the injection of the 6-amino-pyrimidine.

The intravenous administration of $5 \mathrm{mgm}$. of 2-methyl-5-methoxyethyl-6-amino-pyrimidine to 5 normal individuals increased the urinary excretion of the PAYF during the next 24 hours in 4 of the 5 instances from 20 per cent to 127 per cent. The average increase was 72 per cent (Figure 4, Table XIV). The excretion of PAYF by the fifth individual in the 24-hour test period was 20 per cent less than that of his average excretion. It is interesting to note that the urinary output of PAYF after the injection of $5 \mathrm{mgm}$. of 2-methyl-5methoxyethyl-6-amino-pyrimidine is considerably

TABLE XIV

\begin{tabular}{|c|c|c|c|c|c|c|c|}
\hline \multirow{3}{*}{ Subject } & \multicolumn{4}{|c|}{ Control period } & \multicolumn{3}{|c|}{ After injection } \\
\hline & \multirow{2}{*}{$\begin{array}{l}\text { Num- } \\
\text { ber } \\
\text { of } \\
\text { days }\end{array}$} & \multirow{2}{*}{$\begin{array}{l}\text { Urinary } \\
\text { PAYF } \\
\text { range per } \\
\text { day }\end{array}$} & \multirow{2}{*}{$\begin{array}{l}\text { Aver- } \\
\text { age } \\
\text { per } \\
\text { day }\end{array}$} & \multirow{2}{*}{$\begin{array}{l}\text { Highest } \\
\text { per cent } \\
\text { daily } \\
\text { variation }\end{array}$} & \multirow{2}{*}{$\begin{array}{l}24- \\
\text { hour } \\
\text { out- } \\
\text { put }\end{array}$} & \multicolumn{2}{|c|}{$\begin{array}{l}\text { Per cent } \\
\text { increase over }\end{array}$} \\
\hline & & & & & & $\begin{array}{l}\text { Pre- } \\
\text { vious } \\
\text { day }\end{array}$ & $\begin{array}{l}\text { Aver- } \\
\text { age } \\
\text { con- } \\
\text { trol } \\
\text { day }\end{array}$ \\
\hline $\begin{array}{l}\text { M. H. } \\
\text { A. B. } \\
\text { P. R. } \\
\text { A. S. } \\
\text { J. H. }\end{array}$ & $\begin{array}{l}4 \\
2 \\
4 \\
3 \\
6\end{array}$ & $\begin{array}{l}300-580 \\
169-220 \\
408-514 \\
222-332 \\
351-910\end{array}$ & $\begin{array}{l}426 \\
194 \\
460 \\
250 \\
556\end{array}$ & $\begin{array}{r}93 \\
35 \\
41 \\
50 \\
159\end{array}$ & $\begin{array}{l}408 \\
356 \\
553 \\
568 \\
880\end{array}$ & $\begin{array}{r}11 \\
13 \\
18 \\
156 \\
43\end{array}$ & $\begin{array}{r}-20 \\
84 \\
20 \\
127 \\
58\end{array}$ \\
\hline
\end{tabular}

* Expressed in thiamin equivalents.

less than the urinary output of PAYF after the injection of $5 \mathrm{mgm}$. of thiamin (Table XIII).

This observation suggested the possibility that the form in which the pyrimidine degradation product of thiamin occurs in the body is not the 2-methyl-5-methoxyethyl-6-amino-pyrimidine. Therefore, it seemed advisable to inject another active pyrimidine which probably bore a closer relationship to thiamin degradation than did the synthetic 2-methyl-5-methoxyethyl-6-amino derivative. The pyrimidine selected was that formed by the alkaline cleavage of the vitamin. This compound was suggested and prepared by the Fleischmann Laboratories and, of that preparation, amounts equivalent to $5 \mathrm{mgm}$. of 2-methyl-5methoxyethyl-6-amino-pyrimidine were given in- 


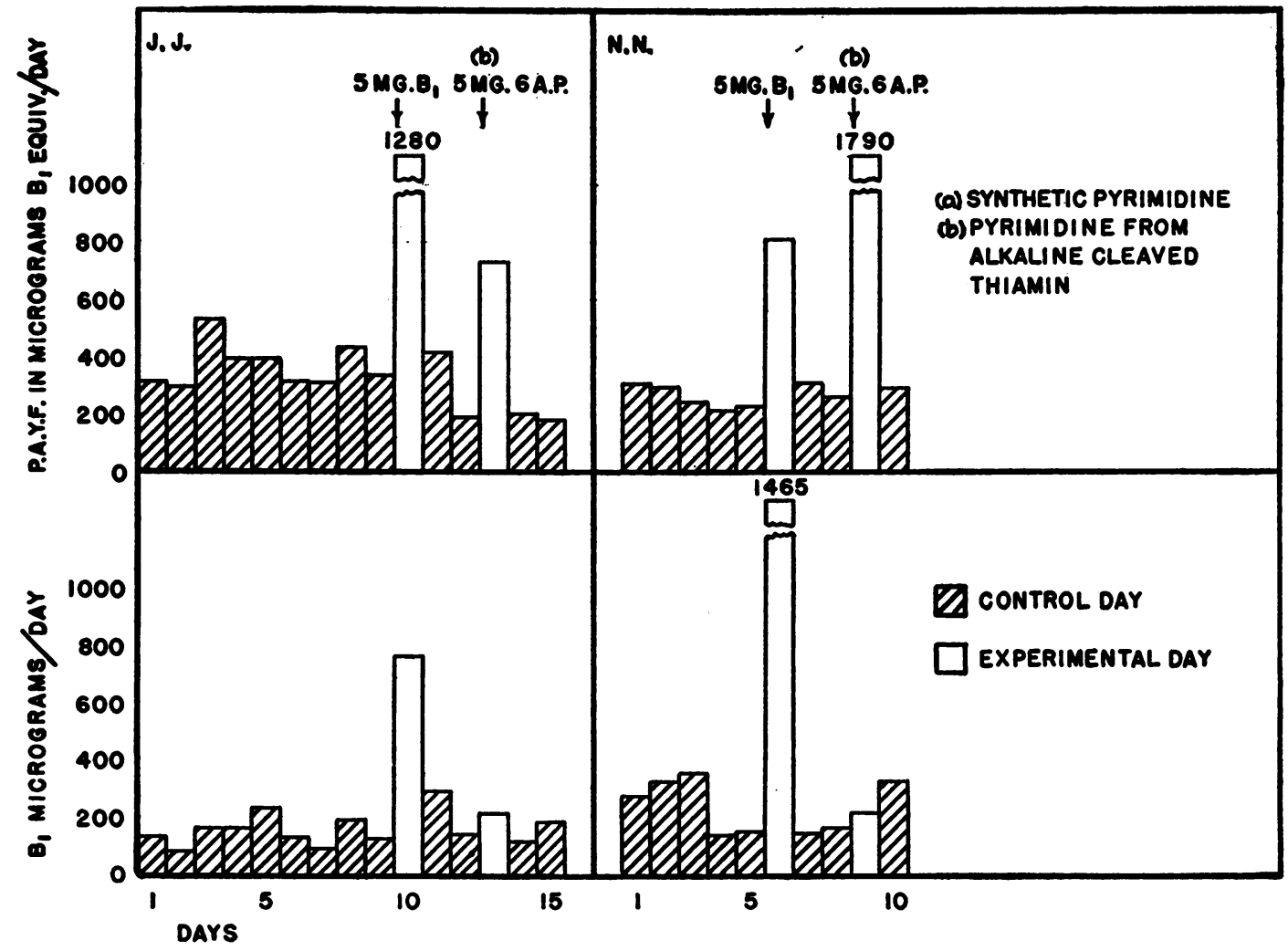

FIG. 4A

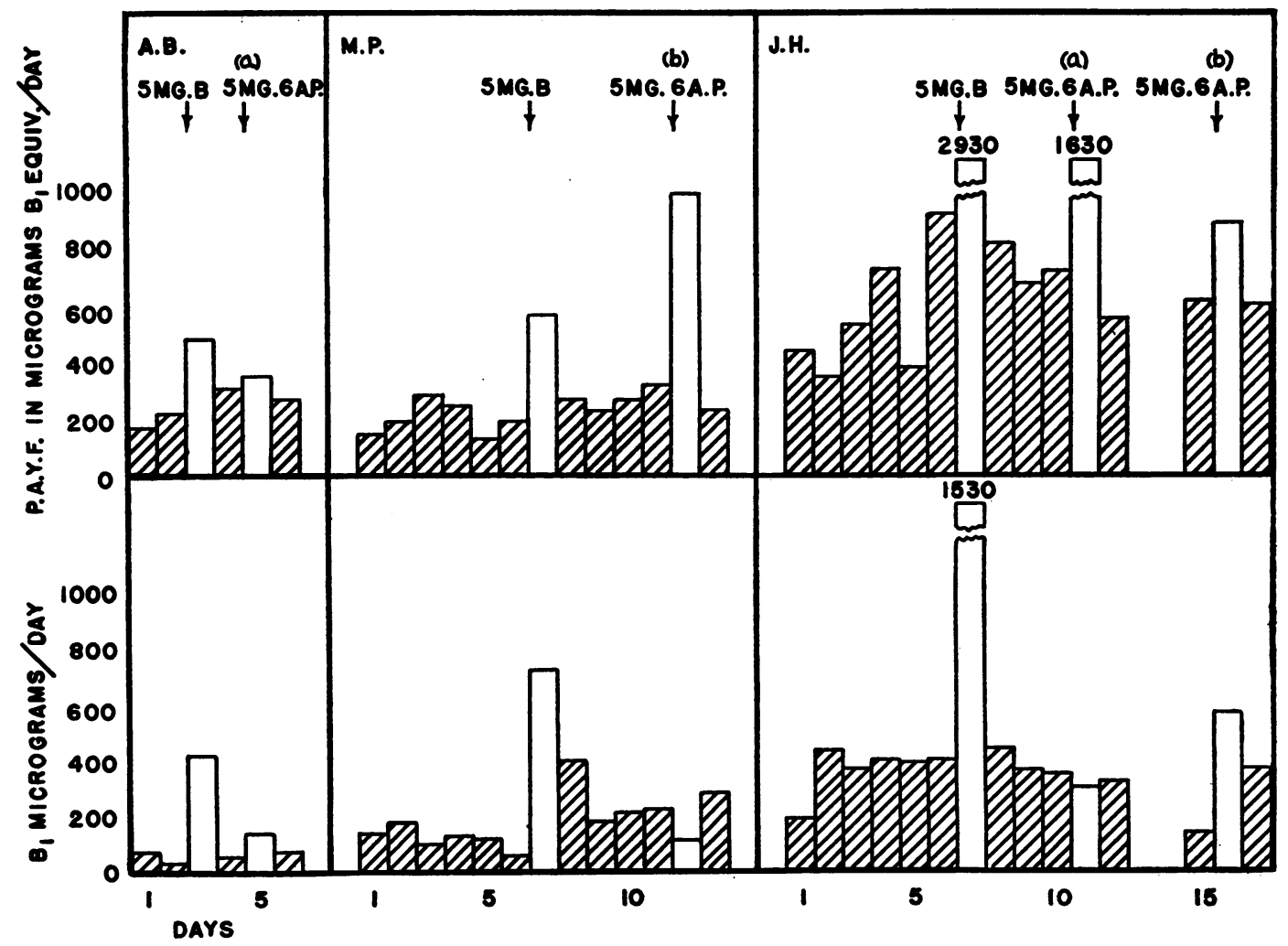

Fig. 4B 


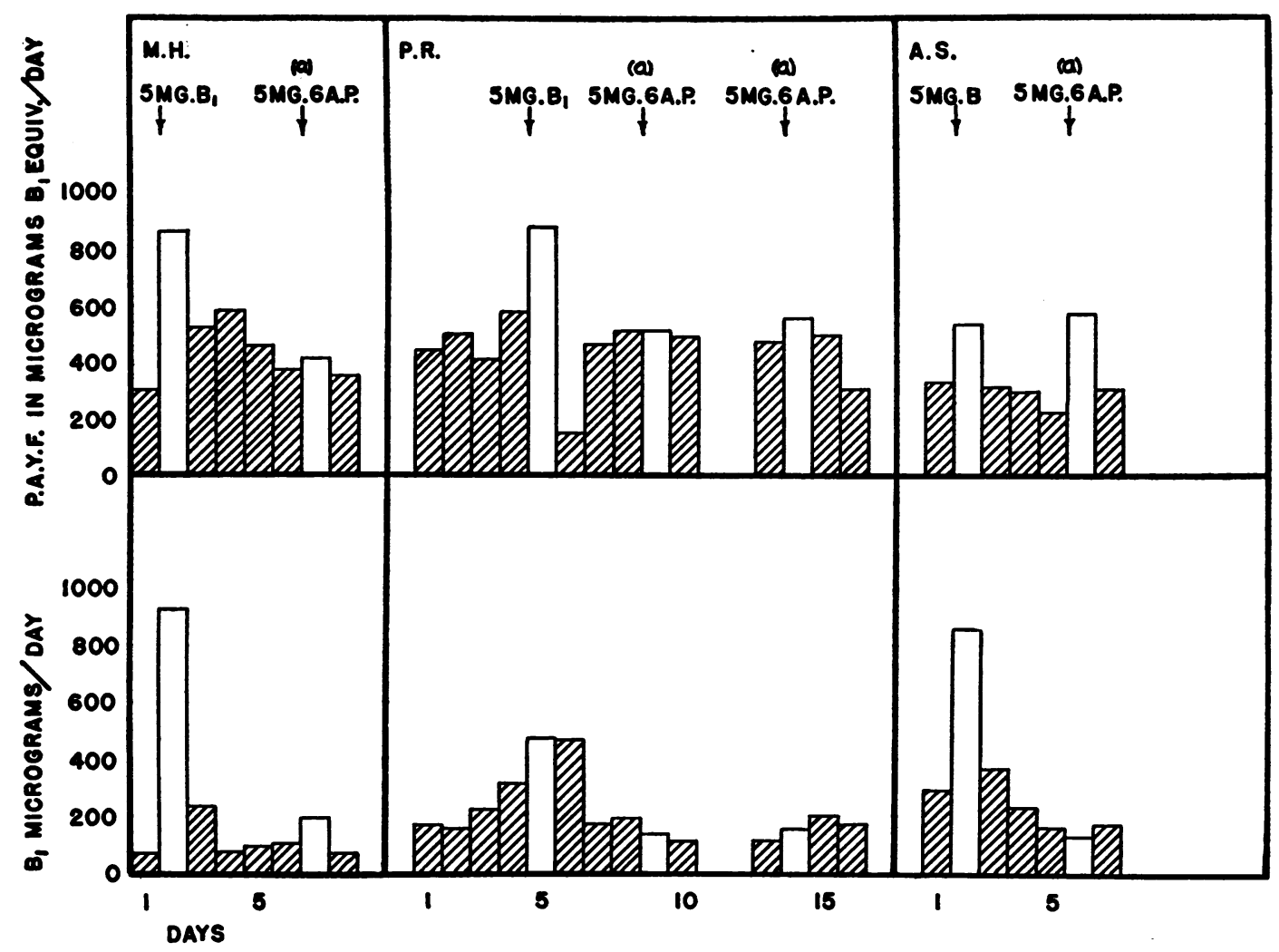

Frg. 4C

Fig. 4-A, B, C. The Urinary Excretion of Thinmin and of PAYF in Normal Individuals after the Intravenous Administration of 5 Mgm. of Thiamin and 5 Mgm. of 6-Amino-Pyrimidine

travenously to 4 normal individuals. (However, the volume of this material which contained 5.0 mgm. of pyrimidine compound also contained 1.24 mgm. of thiamin.)

The results of the use of the pyrimidine formed

TABLE XV

Micrograms of thiamin excreted per day in the urine of individuals before and after the intravenous injection of 2-methyl-5-methoxyethyl-6-amino-pyrimidine

\begin{tabular}{|c|c|c|c|c|c|c|c|}
\hline \multirow{3}{*}{ Subject } & \multicolumn{4}{|c|}{ Control period } & \multicolumn{3}{|c|}{ After injection } \\
\hline & \multirow{2}{*}{$\begin{array}{l}\text { Num- } \\
\text { ber } \\
\text { of } \\
\text { days }\end{array}$} & \multirow{2}{*}{$\begin{array}{l}\text { Urinary } \\
\text { thiamin } \\
\text { range per } \\
\text { day }\end{array}$} & \multirow{2}{*}{$\begin{array}{l}\text { Aver- } \\
\text { age } \\
\text { per } \\
\text { day }\end{array}$} & \multirow{2}{*}{$\begin{array}{l}\text { Highest } \\
\text { per cent } \\
\text { daily } \\
\text { variation }\end{array}$} & \multirow{2}{*}{$\begin{array}{l}\text { 24- } \\
\text { hour } \\
\text { out- } \\
\text { put }\end{array}$} & \multicolumn{2}{|c|}{$\begin{array}{l}\text { Per cent } \\
\text { increase over }\end{array}$} \\
\hline & & & & & & $\begin{array}{c}\text { Pre- } \\
\text { vious } \\
\text { day }\end{array}$ & $\begin{array}{l}\text { Aver- } \\
\text { age } \\
\text { con- } \\
\text { trol } \\
\text { day }\end{array}$ \\
\hline $\begin{array}{l}\text { M. H. } \\
\text { A. B. } \\
\text { P. R. } \\
\text { A. S. } \\
\text { J. H. }\end{array}$ & $\begin{array}{l}4 \\
2 \\
4 \\
3 \\
6\end{array}$ & $\begin{array}{r}66-101 \\
25-63 \\
158-314 \\
158-296 \\
179-421\end{array}$ & $\begin{array}{r}83 \\
44 \\
214 \\
229 \\
350\end{array}$ & $\begin{array}{r}53 \\
152 \\
99 \\
87 \\
135\end{array}$ & $\begin{array}{l}195 \\
136 \\
152 \\
125 \\
558\end{array}$ & $\begin{array}{r}93 \\
170 \\
-20 \\
-20 \\
340\end{array}$ & $\begin{array}{r}135 \\
209 \\
-28 \\
-50 \\
60\end{array}$ \\
\hline
\end{tabular}

by the cleavage of the vitamin are included in Tables XVI and XVII. The 24-hour urinary excretions of PAYF which followed the intravenous injection of the alkaline-cleavage product were significantly higher than those found after the administration of equivalent amounts of the 5methoxy-pyrimidine, but the recoveries of PAYF in the urine still were not quantitative. The urinary excretion of PAYF by the 4 individuals during the 24 hours which followed their injection of alkaline-cleaved vitamin ranged only from 728 to 1790 micrograms, or from 100 to 589 per cent more than their average daily urinary output of the compound. A part of this increased excretion of PAYF after the administration of the cleaved thiamin might have been due to the 1240 micrograms of the vitamin which were injected simultaneously.

It is to be noted that the intravenous injection of either of these pyrimidine preparations into the 9 normal individuals was followed by a signifi- 
cantly increased urinary excretion of thiamin in only 2 (Tables XV and XVII).

The results obtained in these experiments indicate that the intravenous administration of thia$\mathrm{min}$ is followed consistently by significantly in-

\section{TABLE XVI}

Micrograms of $P A Y F^{*}$ excreted per day in the urine of individuals before and after the intravenous injection of the alkaline-cleaved products of thiamin

\begin{tabular}{|c|c|c|c|c|c|c|c|}
\hline \multirow{3}{*}{ Subject } & \multicolumn{4}{|c|}{ Control period } & \multicolumn{3}{|c|}{ After injection } \\
\hline & \multirow{2}{*}{$\begin{array}{c}\text { Num- } \\
\text { ber } \\
\text { of } \\
\text { days }\end{array}$} & \multirow{2}{*}{$\begin{array}{l}\text { Urinary } \\
\text { PAYF } \\
\text { range per } \\
\text { day }\end{array}$} & \multirow{2}{*}{$\begin{array}{l}\text { Aver- } \\
\text { age } \\
\text { per } \\
\text { day }\end{array}$} & \multirow{2}{*}{$\begin{array}{l}\text { Highest } \\
\text { per cent } \\
\text { daily } \\
\text { variation }\end{array}$} & \multirow{2}{*}{$\begin{array}{l}\text { 24- } \\
\text { hour } \\
\text { out- } \\
\text { put }\end{array}$} & \multicolumn{2}{|c|}{$\begin{array}{c}\text { Per cent } \\
\text { increase over }\end{array}$} \\
\hline & & & & & & $\begin{array}{l}\text { Pre- } \\
\text { vious } \\
\text { day }\end{array}$ & $\begin{array}{l}\text { Aver- } \\
\text { age } \\
\text { con- } \\
\text { trol } \\
\text { day }\end{array}$ \\
\hline $\begin{array}{l}\text { J. J. } \\
\text { J. H. } \\
\dot{\mathrm{M}} . \mathbf{P} . \\
\text { N. N. }\end{array}$ & $\begin{array}{l}9 \\
6 \\
6 \\
5\end{array}$ & $\begin{array}{l}294-525 \\
351-910 \\
126-282 \\
215-300\end{array}$ & $\begin{array}{l}368 \\
556 \\
198 \\
263\end{array}$ & $\begin{array}{r}178 \\
159 \\
124 \\
40\end{array}$ & $\begin{array}{r}728 \\
1630 \\
978 \\
1790\end{array}$ & $\begin{array}{l}287 \\
128 \\
204 \\
589\end{array}$ & $\begin{array}{l}100 \\
193 \\
393 \\
589\end{array}$ \\
\hline
\end{tabular}

* Expressed in thiamin equivalents.

TABLE XVII

Micrograms of thiamin excreted per day in the urine of individuals before and after the intravenous injection of the alkaline-cleaved products of thiamin

\begin{tabular}{|c|c|c|c|c|c|c|c|}
\hline \multirow{3}{*}{ Subject } & \multicolumn{4}{|c|}{ Control period } & \multicolumn{3}{|c|}{ After injection } \\
\hline & \multirow{2}{*}{$\begin{array}{l}\text { Num- } \\
\text { ber } \\
\text { of } \\
\text { days }\end{array}$} & \multirow{2}{*}{$\begin{array}{c}\text { Urinary } \\
\text { thiamin } \\
\text { range per } \\
\text { day }\end{array}$} & \multirow{2}{*}{$\begin{array}{l}\text { Aver- } \\
\text { age } \\
\text { per } \\
\text { day }\end{array}$} & \multirow{2}{*}{$\begin{array}{l}\text { Highest } \\
\text { per cent } \\
\text { daily } \\
\text { variation }\end{array}$} & \multirow{2}{*}{$\begin{array}{l}24- \\
\text { hour } \\
\text { out- } \\
\text { put }\end{array}$} & \multicolumn{2}{|c|}{$\begin{array}{c}\text { Per cent } \\
\text { increase over }\end{array}$} \\
\hline & & & & & & $\begin{array}{l}\text { Pre- } \\
\text { vious } \\
\text { day }\end{array}$ & $\begin{array}{l}\text { Aver- } \\
\text { age } \\
\text { con- } \\
\text { trol } \\
\text { day }\end{array}$ \\
\hline $\begin{array}{l}\text { J. J. } \\
\text { J. }{ }_{\text {H. }} \\
\text { M. P. } \\
\text { N. N. }\end{array}$ & $\begin{array}{l}9 \\
6 \\
6 \\
5\end{array}$ & $\begin{array}{r}76-227 \\
179-421 \\
53-168 \\
140-348\end{array}$ & $\begin{array}{l}140 \\
350 \\
111 \\
270\end{array}$ & $\begin{array}{l}200 \\
135 \\
216 \\
143\end{array}$ & $\begin{array}{l}202 \\
290 \\
102 \\
210\end{array}$ & $\begin{array}{r}42 \\
-15 \\
-50 \\
31\end{array}$ & $\begin{array}{r}44 \\
-17 \\
9 \\
-22\end{array}$ \\
\hline
\end{tabular}

creased concentrations of PAYF in the white cells and in the urine. The injection of two biologically active pyrimidine compounds is followed by no consistent change in the urinary excretion of thiamin and by a less marked increase in urinary excretion of PAYF than that which followed the administration of thiamin. These results, then, would support the hypothesis that, normally, the PAYF which occurs in blood cells and urine is formed from the vitamin during its metabolism.

\section{DISCUSSION}

The average thiamin level of the normal white cells was found to be about 10 times that of the normal erythrocytes, a distribution similar to that of vitamin $B_{2}$ (15) and of vitamin $C$ (16). The greater concentrations of vitamins $B_{1}, B_{2}$ and $C$ in the white cells probably can be explained by the fact that, of the several blood components, the white cells most closely resemble actively metabolizing tissue. The respiratory rate $\left(\mathrm{QO}_{2}\right)$ of leukocytes and platelets also is about 100 to 1000 times that of erythrocytes (17), a ratio of a much higher order of magnitude than that of the distribution of the 3 vitamins which are known to function as essential parts of respiratory enzymes.

The present study would indicate that, in the course of its metabolism, thiamin is broken down to the PAYF compound. The evidence upon which this conclusion is based is that the intravenous administration of thiamin to normal individuals is followed consistently by a significant increase in the concentrations of the PAYF in the blood cells and urine.

It must be recognized, however, that another mechanism could explain this observation-that the PAYF in the blood and urine might have been formed not necessarily as a result of utilization of thiamin by the body, but rather by the spontaneous breakdown of the vitamin. The increased white cell content and urinary excretion of PAYF after the administration of thiamin would reflect, then, only the presence of an increased amount of thiamin with the possibility of greater total breakdown. However, if this were the case, namely, that all the PAYF was a spontaneous breakdown product of thiamin, the administration of the vitamin to all individuals under all circumstances should result in the spontaneous production of PAYF. This should be true irrespective of the existence of an abnormality in the utilization of thiamin, since such an abnormality should not alter the rate of spontaneous decomposition which the vitamin undergoes in the organism.

This explanation of spontaneous decomposition of thiamin, however, is not tenable because such an abnormality in the metabolism of the vitamin has been found in the leukemic patient. The discovery of that abnormality provided an oppor- 
tunity of subjecting to experimental test the thesis just discussed. The administration of thiamin to the leukemic individual is not followed by any increase in the PAYF content of his white cells. The details of that study form the subject of a separate paper (18), but the observation is introduced here to indicate that the mere presence of thiamin is not enough to account for the simultaneous production of PAYF. The observation that an increased requirement of thiamin is associated with an increased consumption of carbohydrate foods, with pregnancy, and with fevers (19) also indicates that some of the vitamin is destroyed during its physiologic activity. At present, it would appear, therefore, that the PAYF is one of the metabolic products of thiamin in the human organism.

The work of Robbins et al. (14) indicates that in the animal organism thiamin cannot be synthesized from its pyrimidine analogue. Likewise, from the present experiments it would appear that in man no significant amount of the vitamin could be formed consistently from the administration either of the synthetic 2-methyl-5-methoxyethyl-6-amino-pyrimidine, or of the pyrimidine produced by the alkaline cleavage of thiamin. Both of those pyrimidines are active accelerators of yeast fermentation and are related closely in chemical structure to the pyrimidine incorporated in the thiamin molecule. However, the fact that the administration of either of those substances was followed by a smaller urinary excretion of PAYF than occurred after the administration of the vitamin itself would suggest strongly that the PAYF formed from thiamin differs from the two pyrimidines used in this investigation. Until the PAYF normally found in blood and urine can be isolated and administered, no conclusion can be drawn as to its ability to produce thiamin in man.

\section{CONCLUSIONS}

1. Methods for the determination of thiamin and the pyrimidine accelerator of yeast fermentation (PAYF) have been adapted for application to the white cells and erythrocytes of normal individuals.

2. The thiamin concentration of the leukocytes and platelets is about 10 times that of the erythro- cytes, a distribution which probably reflects the respiratory activity of the white blood cells.

3. The white blood cell levels of thiamin reflect the thiamin deficiency and saturation of the body.

4. White cells do not differ in their capacity to absorb thiamin, but can absorb only a limited, maximum amount of the vitamin.

5. In the course of its metabolic activity, thiamin probably is broken down to the PAYF compound.

After this communication was accepted for publication, Wertz and Mitchell (20) demonstrated that the oral administration of from 2 to $4 \mathrm{mgm}$. of thiamin to normal individuals was followed by an increased urinary excretion of PAYF. These investigators conclude that PAYF is a metabolic breakdown product of the vitamin.

\section{BIBLIOGRAPHY}

1. Borson, H. J., Clinical application of the thiochrome reaction in the study of thiamin deficiency. Ann. Int. Med., 1940, 14, 1.

2. Melnick, D., and Field, H., Jr., The thiamin clearance as an index of nutritional status. J. Biol. Chem. (Proc.), 1941, 140, 35.

3. Harris, L. J., and Leong, P. C., The excretion of vitamin $B_{1}$ in human urine. Lancet, 1936, 1, 886.

4. Pollack, H., Ellenbey, M., and Dolger, H., The excretion of thiamin and its degradation products in man. Proc. Soc. Exper. Biol. and Med., 1941, 47, 414.

5. Melnick, D., and Field, H., Jr., Chemical determinations of vitamin $B_{1}$. II. Method for estimation of the thiamin content of biological materials with the diazotized $p$-aminoacetophenone reagent. J. Biol. Chem., 1939, 127, 515.

6. Hennessy, D. J., and Cerecido, L. R., The determination of free and phosphorylated thiamin by a modified thiochrome assay. J. Am. Chem. Soc., 1939, 61, 179.

7. Atkin, L., Schultz, A. S., and Frey, C. N., Ultramicrodetermination of thiamin by the fermentation method. J. Biol. Chem., 1939, 129, 471.

8. Schultz, A. S., Atkin, L., and Frey, C. N., The specificity of the fermentation test for vitamin $B_{1}$. J. Am. Chem. Soc., 1938, 60, 3084.

9. Schultz, A. S., Atkin, L., and Frey, C. N., A fermentation test for vitamin B. J. Am. Chem. Soc., 1937, 59, 2457.

10. Banga, I., Ochoa, S., and Peters, R. A., Pyruvate oxidation in brain. VI. The active form of vitamin $B_{1}$ and the rôle of $C_{4}$ dicarboxylic acids. Bioch. J., 1939, 36, 1109.

11. Schultz, A. S., Light, R., and Frey, C. N., A method for the determination of thiamin and certain of its 
metabolic products in urine. J. Biol. Chem., 1940, 136, 713.

12. Robbins, W. J., Organisms requiring vitamin $B_{1}$ Proc. Nat. Acad. Sc., 1938, 24, 53.

13. Bonner, J., and Buchman, E., The synthesis and destruction of vitamin $B_{1}$ by phycomyces. Proc. Nat. Acad. Sc., 1939, 25, 164.

14. Robbins, W. J., Bartley, M. A., Hogan, A. G., and Richardson, L. R., Pyrimidine and thiazol intermediates as substitutes for vitamin $B_{1}$. Proc. Nat. Acad. Sc., 1937, 23, 388.

15. Lund, C. C., Private communication.

16. Butler, A. M., and Cushman, M., Distribution of ascorbic acid in the blood and its clinical significance. J. Clin. Invest., 1940, 19, 459.
17. MacLeod, J., and Rhoads, C. P., Metabolism of leukocytes in Ringer phosphate and in serum. Proc. Soc. Exper. Biol. and Med., 1939, 41, 268.

18. Abels, J. C., Gorham, A. T., Craver, L., and Rhoads, C. P., The measurement and metabolism of thiamin and a pyrimidine stimulating yeast fermentation found in the blood cells and urine of patients with leukemia. J. Clin. Invest., 1942, 21, 177.

19. Cowgill, G. R., The Vitamin B Requirement of Man. Yale Univ. Press, New Haven, 1934.

20. Wertz, A. W., and Mitchell, H. S., Thiamin and pyrimidine studies on older subjects. Proc. Soc. Exper. Biol. and Med., 1941, 48, 259. 